\title{
A Concise Route to MK-4482 (EIDD-2801)
}

\author{
Vasudevan, N. a; Ahlqvist, Grace P.b; McGeough, Catherine P. b; Paymode, Dinesh J. ; Cardoso, Flavio
} S.P. ; Lucas, Tobias ${ }^{\mathrm{c}}$; Dietz, Jule-Philippc; Opatz, Tillc; Jamison, Timothy, F. ${ }^{\mathrm{b}}$; Gupton, B. Frank ${ }^{\mathrm{a}}$; Snead, David R. ${ }^{\mathrm{a}, *}$

\section{AUTHOR ADDRESS}

a) Medicines for All Institute, 737 N. $5^{\text {th }}$ St., Box 980100, Richmond VA, 23298-0100

b) Department of Chemistry, Massachusetts Institute of Technology, 77 Massachusetts Ave, Cambridge, Massachusetts, 02139

c) Department of Chemistry, Johannes Gutenberg University, Duesbergweg 10-14, 55128 Mainz

\section{Supporting Information Placeholder}

\begin{abstract}
A two-step route to MK-4482 (EIDD-2801, 1) was developed consisting of an esterification and hydroxamination of cytidine. The reactions can be conducted in either order with overall yields of $67 \%$ (first step-esterification) and 37\% (first stephydroxamination). Selective esterification of the nucleoside's primary alcohol by enzymatic means eliminated the need for diol protection/deprotection, and direct transamination with hydroxylamine precluded the necessity of activating the nucleobase for amine coupling. This results in a significant advancement over the reported synthesis which is formed in at best $17 \%$ yield. The step count is reduced from five transformation to two, and the more expensive uridine is replaced with the more available cytidine.
\end{abstract}

Remdesivir has presented itself as an option for COVID-19 treatment; ${ }^{1 a}$ however, improvements upon this initial solution are still desired. Fulfilling demand is complicated by issues related to raw material supply, ${ }^{1 \mathrm{~b}, \mathrm{c}}$ price, ${ }^{1 \mathrm{~d}}$ synthetic route length. ${ }^{2}$ MK-4482 (EIDD-2801) ${ }^{3}$ presents an interesting complement to remdesivir for COVID-19 treatment. It is structurally simple in comparison, and it can likely be made from abundant raw materials. These factors would be expected to alleviate supply chain difficulties and reduce costs. Encouragingly, EIDD-2801 shows potential to treat mice with remdesivir resistant strains of COVID-19, and the API is orally bioavailable. These advantages prompted Merck to license the drug candidate from Ridgeback Biotherapeutics. ${ }^{4}$

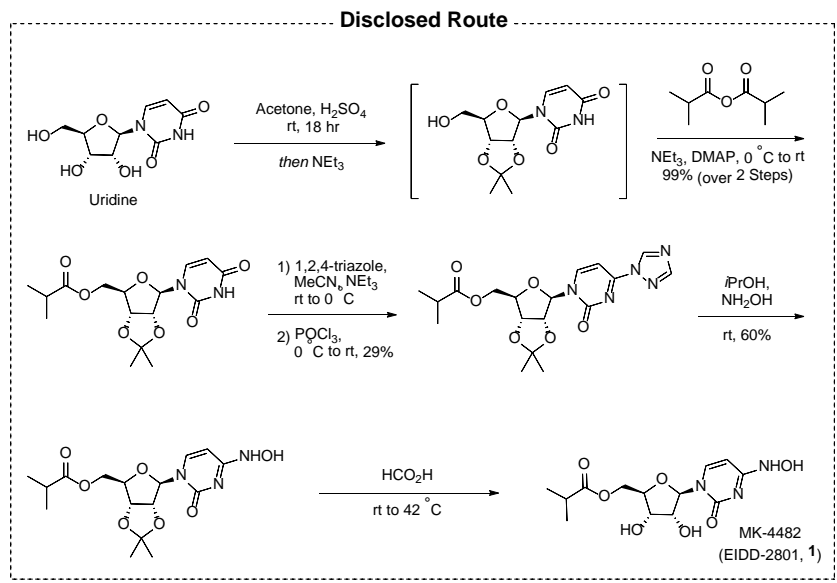

Figure 1: The first generation route to EIDD-2801 from uridine.
The initial disclosure of EIDD-2801 is the only synthesis which appears in the open literature (Fig. 1), and not unexpectedly there are significant opportunities for improvement over this early route. ${ }^{5}$

- The API is constructed over five chemical transformations

- The step count is lengthened by derivatizations and protections.

- The route suffers from low yield (17\% maximum, yield of diol deprotection not disclosed)

- Uridine, an expensive material of limited availability, is the synthetic starting point.

Building the API from cytidine instead of uridine presents several advantages. First, raw material costs can be decreased because cytidine is $\sim 40 \%$ of the price of uridine. Secondly, there is potential to reduce the synthesis to a two-step sequence comprising esterification and transamination with hydroxylamine (Fig. 2).

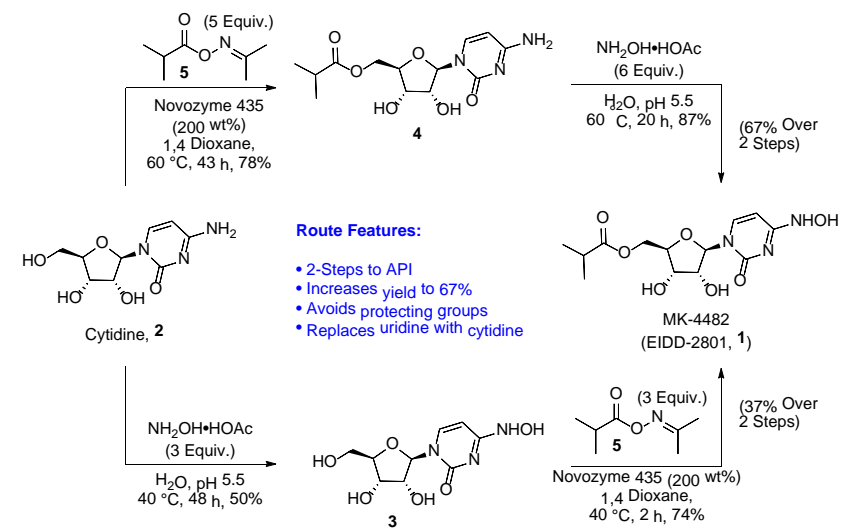

Figure 2: A new route to MK-4482 from cytidine.

We began our exploration by examining direct transamination of cytidine with hydroxylamine. ${ }^{6}$ Older literature studies suggested that mono-hydroxamination can be achieved under the right concentration, temperature and $\mathrm{pH}$, while minimizing over-reaction of substrate. ${ }^{6 a, b}$ More recently this finding was repeated by Purohit with preparative HPLC separation ${ }^{6 \mathrm{c}}$ while Painter claimed difficulties with the procedure leading to $20 \%$ yield. ${ }^{6 \mathrm{~d}}$ In our hands, with slight adjustment of reaction conditions, $N(4)$-hydroxycytidine (NHC, 3) was synthesized in 70\% AY. Use of hydroxylamine acetate rather than the chloride or sulfate helped manage $\mathrm{pH}$ control, 
and limiting the equivalents prevented over-amination. Importantly, upon concentration NHC was isolated by simple crystallization directly from the reaction mixture in $50 \%$ isolated yield. We also explored transamination of cytidine isobutyryl ester $\mathbf{4}$ and were quite pleased to find that similar conditions worked well and left the ester intact. MK-4482 was obtained from 4 in $87 \%$ IY, demonstrating viability of direct hydroxamination from either cytidine pathway.

Selective acylation remained as the largest technical uncertainty toward production of a shorter, protecting group free route to MK4482. The esterification of NHC would need to be selective for one of four hydroxyl groups, and the literature suggests the $N$-hydroxy group is most reactive toward acylation by chemical means. ${ }^{6 d, 7}$ Enzyme catalyzed esterification has achieved this goal for a variety of cytidine derivatives, ${ }^{8}$ particularly by making use of oxime esters for the transesterification. ${ }^{8 a}$ We were hopeful that our substrate would be chemically compatible with the transformation, and curious whether this approach would work to form an $\alpha$-branched ester.

Immobilized CALB (Candida Antarctica Lipase B) provided the desired selectivity for both substrates 2 and 3 . Isobutyric oxime ester $\mathbf{5}$ was used as the acyl transfer agent with solid supported enzyme (200 wt\%, $1.5 \mathrm{~mol} \%$ ). A sufficient excess of the oxime ester was necessary to drive the reaction to completion, and early results have been best with 1,4-dioxane. MK-4482 was isolated in 74\% yield from 3 and $\mathbf{4}$ was isolated in 78\% yield from cytidine. A traditional chemically catalyzed acylation was developed to provide a non-enzymatic option to reach 4 . $^{9}$ Conversion was stopped at $90 \%$ to halt over-acylation of product, resulting in an isolated yield of $76 \%$ of 4 .

This completes two concise routes to MK-4482, which differ in the order of synthetic transformations. When conducting esterification first, MK-4482 is obtained in $67 \%$ and $37 \%$ when hydroxyamination is conducted first. The step count is reduced from five transformations to two, and the more expensive uridine is replaced with cytidine. The use of protecting groups and derivatization is avoided. We plan to further report on the optimization of this early stage result to refine catalyst loadings, solvent selection, and yield while developing process-amenable isolation sequences.

\section{ASSOCIATED CONTENT}

\section{Supporting Information}

The Supporting Information is available free of charge on the ACS Publications website.

Experimentals (PDF)

Compound characterization (PDF)

\section{AUTHOR INFORMATION}

\section{Corresponding Author}

David R. Snead

737 N. $5^{\text {th }}$ St.

Box 980100

Richmond, Virginia 23298-0100

email: drsnead@vcu.edu

\section{Author Contributions}

${ }^{\dagger}$ These authors contributed equally.

\section{Notes}

The authors declare no competing financial interests.
We thank the Bill and Melinda Gates Foundation for theirlongstanding support of our research. In addition, we express gratitude to Trevor Laird and John Dillon for their thoughtful commentary and discussion throughout this work. We also thank Silpa Sundaram and Dr. Susan Hershenson for fostering a highly collaborative and dynamic ecosystem.

\section{REFERENCES}

1) a) An Open Letter from our Chairman \& CEO, Gilead Sciences, Inc. https://stories.gilead.com/articles/an-open-letter-from-ourchairman-and-ceo-april-29 (Accessed July 1, 2020). b) Working to Supply Remdesivir for COVID-19, Gilead Sciences, Inc. https://www.gilead.com/purpose/advancing-global-health/covid19/working-to-supply-remdesivir-for-covid-19 (Accessed July 1, 2020). c) Gilead Sciences Statement on Expanding Global Supply of Investigational Antiviral Remdesivir, Gilead Sciences, Inc. https://www.gilead.com/news-and-press/company-statements/gilead-sciences-statement-on-remdesivir-global-supply (Accessed July 1, 2020). d) An Open Letter from Daniel O’Day, Chairman \& CEO, Gilead Sciences, Gilead Sciences, Inc. https://www.gilead.com/news-and-press/press-room/press-releases/2020/6/anopen-letter-from-daniel-oday-chairman--ceo-gilead-sciences (Accessed July 1, 2020).

2) a)Siegel, D.; Hui, H.C.; Doerffler, E.; Clarke, M.O.; Chun, K.; Zhang, L.; Neville, S.; Carra, E.; Lew, W.; Ross, B.; Wang, Q.; Wolfe, L.; Jordan, R.; Soloveva, V.; Knox, J.; Perry, J.; Perron, M.; Stray, K.M.; Barauskas, O.; Feng, J.Y.; Xu, Y.; Lee, G.; Rheingold, A.L.; Ray, A.S.; Bannister, R.; Strickley, R.; Swaminathan, S.; Lee, W.A.; Bavari, S.; Cihlar, T.; Lo, M.K.; Warren, T.K.; Mackman, R.L. J. Med. Chem., 2017, 60, 1648-1661. b) De Savi, C.; Hughes, D.L.; Kvaerno, L. Org. Process Res. Dev., 2020, 24, 940976. c) Vieira, T.; Stevens, A.C.; Chtchemelinine, A.; Gao, D.; Badalov, P.; Heumann, L. Org. Process Res. Dev., 2020, ASAP. c) Xue, F.; Zhou, X.; Zhou, R.; Zhou, X.; Xiao, D.; Zhong, W.; Gu, E.; Guo, W.; Xiang, J.; Wang, K.; Yang, L.; Qin, Y. Org. Process Res. Dev., 2020, ASAP.

3) a) Sheahan, T.P.; Sims, A.C.; Zhou, S.; Graham, R.L.; Pruijssers, A.J.; Agostini, M.L.; Leist, S.R.; Schafer, A.; Dinnon III, K.H.; Stevens, L.J.; Chappel, J.D.; Lu, X.; Hughes, T.M.; George, A.S.; Hill, C.S.; Montgomery, S.A.; Brown, A.J.; Bluemling, G.R.; Natchus, M.G.; Saindane, M.; Kolykhalov, A.A.; Painter, G.; Harcourt, J.; Tamin, A.; Thornburg, N.J.; Swanstrom, R.; Denison, M.R.; Baric, R.S. Sci. Transl. Med., 2020, 12, ASAP. b) Halford, B. "An emerging antiviral takes aim at COVID-19", Chem. Eng. News, 2020, 98.

4) Cross, R. "Merck \& Co. joins race for COVID-19 vaccines and therapies”, Chem. Eng. News, 2020, 98.

5) a) Painter, G.R.; Bluemling, G.R.; Natchus, M.G.; Guthrie, D. WO2019113462, 2018. b) Painter, G.R.; Perryman, D.; Bluemling, G.R.WO2019173602, 2019.

6) a) Verwoerd, D.W.; Kohlhage, H.; Zillig, W. Nature, 1961, 192, 1038-1040. b) Kochetkov, N.K.; Budovskii, E.I. Organic Chemistry of Nucleic Acids, Part B; Plenum Publishing Corporation: New York, 1972; pp 269-348. c) Purohit, M.K.; Poduch, E.; Wei, L.W.; Crandall, I.E.; To, T.; Kain, K.C.; Pai, E.F.; Kotra, L.P. J. Med. Chem., 2012, 55, 9988-9997. d) Painter, G. R.; Guthrie, D. B.; Bluemling, G. R.; Natchus, M. G., WO2016106050A1, 2016.

7) a) Ivanov, M.A.; Antonova, E.V.; Maksimov, A.V.; Pigusova, L.K.; Belanov, E.F.; Aleksandrova, L.A. Collect. Czech. Chem. Commun., 2006, 71, 1099-1106. b) Schinazi, R.F.; Amblard, F.; Cox, B.D.; Bassit, L.; Zhou, L.; Gavegnano, C. WO2017165489, 2016.

8) a) Wong, C. H.; Chen, S. T.; Hennen, W. J.; Bibbs, J. A.; Wang, Y. F.; Liu, J. L. C.; Pantoliano, M. W.; Whitlow, M.; Bryan, P. N. J. Am. Chem. Soc., 1990, 112, 945-953. b) Li, X.-F.; Zong, M.H.; Yang, R.-D. J. Mol. Catal. B Enzym., 2006, 38, 48-53. c) Wu, H.; Zong, M.; Chen, X. Biotechnol. Appl. Biochem., 2009, 53, 201207. d) Kumar, R.; Kumar, M.; Maity, J.; Prasad, A. K. RSC Adv., 2016, 6, 82432-82438.

9) See Supporting Information for details.

\section{ACKNOWLEDGMENT}


